\title{
Antioxidant effect of Arabian coffee (Coffea arabica L) blended with cloves or cardamom in high-fat diet-fed C57BL/6J mice
}

\author{
Ghedeir M Alshammari ${ }^{*}$, Aristatile Balakrishnan, Abdulrahman Al-Khalifa \\ Department of Food Science and Nutrition, College of Food and Agricultural Science, King Saud University, P.O. Box 2460, \\ Riyadh 11451, Saudi Arabia
}

*For correspondence: Email: aghedeir@ksu.edu.sa; Tel: +966-14698434

Sent for review: 15 December 2016

Revised accepted: 8 June 2017

\begin{abstract}
Purpose: To investigate the antioxidant activity of Coffea Arabica L in high-fat diet (HFD)-fed C57BL/6J mice.

Methods: A decoction of Arabian coffee blended with or without cardamom or cloves was orally administered to HFD-fed C57BL/6J mice for a period of 60 days. At the end of the treatment, blood and tissue samples were taken to evaluate various parameters, including lipid peroxidation markers and antioxidants such as paraoxonase (PON1), superoxide dismutase (SOD), glutathione peroxidase (GPX), vitamin $C$, vitamin $E$, reduced glutathione (GSH) and catalase (CAT).

Results: The activities of antioxidant enzymes (PON1, SOD, CAT, and GPX) and non-enzymatic antioxidants $(G S H$, vitamins $C$ and $E)$ were significantly elevated $(p<0.05)$ in mice administered Arabian coffee plus cardamom compared with those administered HFD alone or coffee alone. The levels of thiobarbituric reactive substances and oxidized LDL antibody (oxLDL-Ab) decreased significantly $(p<0.05)$ in mice administered Arabian coffee plus cardamom compared with those administered Arabian coffee plus cloves.

Conclusion: The results indicate that Arabian coffee blended with cardamom or cloves exhibited enhanced free radical scavenging and antioxidant properties compared with those that received Arabic coffee alone. However, coffee with cardamom had more pronounced effects than coffee with cloves.
\end{abstract}

Keywords: High-fat diet, Diabetes, Antioxidant, Arabian coffee, Cardamom, Cloves

Tropical Journal of Pharmaceutical Research is indexed by Science Citation Index (SciSearch), Scopus, International Pharmaceutical Abstract, Chemical Abstracts, Embase, Index Copernicus, EBSCO, African Index Medicus, JournalSeek, Journal Citation Reports/Science Edition, Directory of Open Access Journals (DOAJ), African Journal Online, Bioline International, Open-J-Gate and Pharmacy Abstracts

\section{INTRODUCTION}

An epidemic of cardiovascular diseases is emerging; in particular, the burden of coronary heart disease is rising in Saudi Arabia [1]. Obesity is correlated with an increase in the number of individuals with metabolic abnormalities and premature cardiovascular disease (CVD). Many oxygenated compounds, particularly aldehydes, such as malondialdehyde (MDA), and conjugated dienes (CD), are produced in the body owing to increased generation of free radicals that damage membrane lipoproteins [2,3]. Hyperglycemia itself causes an increase in free radicals because of auto-oxidation and non-enzymatic protein glycation $[2,3]$.

Antioxidant enzymes, such as superoxide dismutase (SOD), catalase (CAT), and glutathione peroxidase (GPx), and nonenzymatic antioxidants, such as vitamins $C$ and $E$ and reduced glutathione (GSH), play vital roles in alleviating tissue damage caused by the 
accumulation of free radicals [4]. Similarly, paraoxonase (PON1) aryl esterase, a calciumdependent serum esterase, is linked with highdensity lipoproteins (HDL) that participate in protecting LDL from peroxidation [5].

Studies have also indicated that the low-grade systemic inflammatory state that occurs in those who are obese not only affects insulin sensitivity, but also reduces HDL levels and their antioxidant capacity [6]. Correcting low HDL antioxidant capacity might be important for reducing cardiovascular risk, particularly in diabetic subjects. Some pharmacological agents that are currently used for the treatment of type 2 diabetes, such as sulfonylureas, biguanides, thiazolidinedione, and a-glycosidase inhibitors, are limited by their side effects and failure to alter diabetic complications. Innumerable natural sources are yet to be explored for this purpose.

Coffee is highly consumed [7]. People in Saudi habitually enjoy consuming Arabian coffee made from lightly roasted Arabian coffee beans mixed with cardamom [8]. A clear understanding of the effects of coffee on health is vital for making informed choices about coffee consumption. Some studies suggested that coffee consumption reduced the risk of developing Alzheimer's disease, Parkinson's disease, and prostate cancer $[9,10]$. In addition, long-term coffee consumption may be associated with a decreased risk of developing type 2 diabetes [11]. Importantly, oxidative stress is a prime factor that links hyperlipidemia and diabetes in the pathogenesis of atherosclerosis. In this study, the antioxidant activity of Arabian coffee (prepared via traditional methods) was evaluated in high-fat diet (HFD)-fed C57BL/6J mice.

\section{EXPERIMENTAL}

\section{Chemicals}

Trichloroacetic acid, hydrochloric acid, thiobarbituric acid, nitroblue tetrazolium, potassium dichromate, and all other analytical grade chemicals and reagents were procured form Merck Ltd (Germany), Sigma-Aldrich Ltd (USA), and Himedia Ltd (India). Coffee seeds, cardamom, and cloves were purchased from a domestic market in Riyadh, Saudi Arabia.

\section{Preparation of Arabian coffee}

In this study, a mixture of Arabian coffee was prepared without sugar, creamer, or milk as follows. Coffea Arabica $L$ beans were roasted for $10 \mathrm{~min}$, then powdered. Thirty grams of coffee powder was mixed with $1 \mathrm{~L}$ of water and the mixture was boiled for 3-5 min, left at room temperature for $2 \mathrm{~min}$, and then filtered. The mixture was stored at room temperature for further use. The protocol for preparing the decoction was adapted from previous papers [12]. Separate decoctions were prepared with 2.5 $\mathrm{g}$ of ground cardamom, cloves, or both.

\section{Animals and diet}

Male C57BL/6J mice (5 weeks old), weighing 20 to $30 \mathrm{~g}$, were procured from Animal Care of Saudi Arabia, Saudi. The mice were maintained in an air-conditioned room $\left(25 \pm 1^{\circ} \mathrm{C}\right)$ with a $12 \mathrm{~h}$ light/12 $\mathrm{h}$ dark cycle in the animal house at the College of Medicine, King Saud University. Mice were provided feed and water ad libitum. The study was conducted according to the international guidelines of the Committee for the Purpose of Control and Supervision of Experiments on Animals [13] and was approved by Institutional Animals Ethics Committee of Experimental Animal Care Center, College of Pharmacy (reg. no. 108-EACC-2015), King Saud University, approved the study protocol.

The animals were divided into 6 groups of 6 animals each. Mice were fed a standard diet for the first 2 weeks. The standard diet contained crude protein $(22.12 \%)$, crude oil $(4.12 \%)$, crude fiber $(3.18 \%)$, ash $(5.17 \%)$, and sand silica $(1.13 \%)$ with an energy value of $3625 \mathrm{kcal} / \mathrm{kg}$.

The experimental groups and the diets administered are as indicated in Table 1.

\begin{tabular}{ll} 
Group & Diet \\
\hline I & A standard pellet diet and water \\
ad libitum \\
II & A standard pellet diet and water \\
& ad libitum + Plain Arabian coffee \\
III & HFD alone \\
IV & HFD + Arabian coffee + \\
& cardamom \\
V & HFD + Arabian coffee + \\
VI & cardamom + cloves \\
\hline
\end{tabular}

\section{Experimental protocol}

The mice were fed their respective diets orally. The total experimental duration spanned 60 days. At the end of the treatment, the animals were anaesthetized with ketamine $(24 \mathrm{mg} / \mathrm{kg}$ body weight, intramuscular injection) and killed via decapitation. Blood was collected from the jugular vein. Serum and plasma were obtained after centrifugation and used for various biochemical evaluations. Tissues were removed, cleared of blood, and immediately 
transferred to ice-cold containers, homogenized in appropriate buffer, and used to evaluate various parameters as indicated below.

\section{Determination of lipid peroxidation and antioxidants}

\section{Thiobarbituric acid reactive substances (TBARS)}

The concentration of TBARS was estimated using the method described by Ohkawa [14]. In this method, malondialdehyde and other TBARS were reacted with thiobarbituric acid in acidic conditions to generate a pink chromophore, the absorbance of which was read at $535 \mathrm{~nm}$.

\section{SOD}

SOD activity was assayed using the method described by Kakkar et al [15]. The assay is based on inhibition of the formation of NADHphenazinemethosulfate, nitroblue tetrazolium formazan. The reaction was initiated by adding $\mathrm{NADH}$ to the assay mixture. After incubation for $90 \mathrm{~s}$, glacial acetic acid was added to stop the reaction. The color developed at the end of the reaction was extracted into the $n$-butanol layer and measured using a Spectronic 20 at $520 \mathrm{~nm}$.

\section{CAT}

CAT activity was determined using the method described by Sinha [16]. Dichromate in acetic acid was converted to perchromic acid and then to chromic acetate when heated in the presence of $\mathrm{H}_{2} \mathrm{O}_{2}$. The chromic acetate formed was measured at $620 \mathrm{~nm}$. The CAT preparation was allowed to split $\mathrm{H}_{2} \mathrm{O}_{2}$ for various periods of time. The reaction was stopped at different time intervals by adding dichromate-acetic acid mixture and the remaining $\mathrm{H}_{2} \mathrm{O}_{2}$ as chromic acetate was determined colorimetrically.

$G P x$

The activity of GPx was measured using the method described by Rotruck et al [17]. A known amount of enzyme preparation was allowed to react with $\mathrm{H}_{2} \mathrm{O}_{2}$ in the presence of $\mathrm{GSH}$ for a specified period, and then, the remaining amount of GSH was measured.

\section{GSH}

The levels of GSH were estimated using the method described by Ellman [18]. This method was based on the formation of 2-nitro-5- thiobenzoic acid (a yellow colored compound) when 5, 5'-dithio-bis (2-nitrobenzoic acid) (DTNB) was added to compounds containing sulfhydryl groups.

\section{Vitamin C}

The levels of ascorbic acid (vitamin C) were estimated using the method described by Roe and Kuether [19]. The ascorbic acid was converted to dehydroascorbic acid by mixing with norit and then coupled with 2,4dinitrophenylhydrazine (DNPH) in the presence of thiourea, a mild reducing agent. The coupled dinitrophenylhydrazine was converted to a red compound when treated with sulfuric acid.

\section{Vitamin E}

The levels of $\alpha$-tocopherol were estimated by the method described by Baker et al [20]. The method involves reducing ferric ions to ferrous ions using $\alpha$-tocopherol and the formation of a red complex with 2, 2' dipyridyl. Absorbance of the chromophore was measured at $520 \mathrm{~nm}$.

\section{Oxidized $L D L$ antibody (oxLDL $A b$ )}

The levels of oxLDL Ab were estimated using an ImmuLisa Oxidized LDL antibody ELISA kit (IMMCO Diagnostics). PON1 arylesterase activity was measured using a method adapted from Cabana [21].

\section{Statistical analysis}

Statistical evaluation was performed using oneway analysis of variance (ANOVA), which was followed Duncan's multiple range test (DMRT). The analyses were conducted using SPSS 16.0. The significance level was set at $p<0.05$.

\section{RESULTS}

Effect of Arabian coffee, cardamom, and cloves on the levels of plasma and tissue TBARS

Table 1 shows the effect of Arabian coffee, cardamom and cloves on the levels of TBARS in the plasma and tissues of HFD-fed C57BL/6J mice. The HFD-fed mice exhibited elevated levels of TBARS. The administration of Arabian coffee, cardamom and cloves resulted in a significant reduction in the levels of TBARS. This effect was more pronounced in mice administered Coffea Arabica $L$ plus cardamom. 
Table 1: Effect of Arabian coffee, cardamom and cloves on the levels of TBARS in the erythrocyte and tissues of HFD-fed C57BL/6Jdiabetic mice

\begin{tabular}{lcccc}
\hline \hline \multirow{2}{*}{ Group } & Plasma & \multicolumn{3}{c}{ TBARS } \\
\cline { 3 - 5 } & $\begin{array}{c}\text { TBARS } \\
(\mathbf{m m o l} / \mathbf{m L})\end{array}$ & Liver & Kidney & Heart \\
\hline \hline Control & $0.18 \pm 0.1^{\mathrm{a}}$ & $0.78 \pm 0.03^{\mathrm{a}}$ & $1.46 \pm 0.11^{\mathrm{a}}$ & $0.55 \pm 0.04^{\mathrm{a}}$ \\
Control + Arabian coffee & $0.16 \pm 0.01^{\mathrm{a}}$ & $0.77 \pm 0.02^{\mathrm{a}}$ & $1.39 \pm 0.09^{\mathrm{a}}$ & $0.49 \pm 0.03^{\mathrm{a}}$ \\
HFD & $0.50 \pm 0.04^{\mathrm{b}}$ & $2.01 \pm 0.08^{\mathrm{b}}$ & $3.48 \pm 0.25^{\mathrm{b}}$ & $1.90 \pm 0.17^{\mathrm{b}}$ \\
HFD + Arabian coffee + Cardamom & $0.32 \pm 0.03^{\mathrm{c}}$ & $1.42 \pm 0.06^{\mathrm{c}}$ & $2.39 \pm 0.17^{\mathrm{c}}$ & $1.05 \pm 0.07^{\mathrm{c}}$ \\
HFD + Arabian coffee + Cardamom + cloves & $0.23 \pm 0.02^{\mathrm{a}, \mathrm{d}}$ & $0.95 \pm 0.06^{\mathrm{d}}$ & $2.03 \pm 0.15^{\mathrm{a}}$ & $0.91 \pm 0.06^{\mathrm{c}, \mathrm{d}}$ \\
HFD + coffee with cloves & $0.29 \pm 0.03^{\mathrm{c}, \mathrm{e}}$ & $1.21 \pm 0.05^{\mathrm{e}}$ & $2.23 \pm 0.16^{\mathrm{e}}$ & $1.02 \pm 0.07^{\mathrm{c}, \mathrm{e}}$ \\
\hline \hline
\end{tabular}

Values are means $\pm S D$ for six samples from 6 mice in each group; Values not sharing a common superscript differ significantly at $p \leq 0.05$. Duncan's Multiple Range Test (DMRT)

Table 2: Effect of Arabian coffee, cardamom and cloves on the activity of superoxide dismutase in the erythrocyte and tissues of HFD-fed C57BL/6Jdiabetic mice

\begin{tabular}{|c|c|c|c|c|}
\hline \multirow[b]{2}{*}{ Group } & \multirow{2}{*}{$\begin{array}{c}\text { Erythrocyte } \\
\text { SOD } \\
\left(\mathrm{U}^{@} / \mathrm{mg} \mathrm{Hb}\right)\end{array}$} & \multicolumn{3}{|c|}{ Superoxidedismutase ( $\mathrm{U}^{\Theta} / \mathrm{mg}$ protein) } \\
\hline & & Liver & Kidney & Heart \\
\hline Control & $8.47 \pm 0.25^{\mathrm{a}}$ & $7.90 \pm 0.51^{\mathrm{a}}$ & $14.92 \pm 0.60^{\mathrm{a}}$ & $6.52 \pm 0.33^{\mathrm{a}}$ \\
\hline Control + Arabian coffee & $7.75 \pm 0.19^{a}$ & $8.98 \pm 0.61^{a}$ & $13.03 \pm 1.39^{\mathrm{a}}$ & $5.25 \pm 0.22^{a}$ \\
\hline HFD & $3.58 \pm 0.32^{\mathrm{D}}$ & $4.50 \pm 0.40^{\mathrm{D}}$ & $7.98 \pm 0.35^{\mathrm{D}}$ & $3.69 \pm 0.33^{b}$ \\
\hline HFD + Arabian coffee + Cardamom & $6.25 \pm 0.61^{\mathrm{a}, \mathrm{c}}$ & $5.10 \pm 0.65^{c}$ & $10.42 \pm 0.97^{\mathrm{c}, \mathrm{d}}$ & $4.20 \pm 0.19^{c}$ \\
\hline HFD + Arabian coffee + Cardamom + cloves & $8.09 \pm 0.49^{\mathrm{a}, \mathrm{c}}$ & $6.92 \pm 0.63^{\mathrm{C}}$ & $13.20 \pm 0.26^{a, c}$ & $5.19 \pm 0.37^{\mathrm{c}, \mathrm{e}}$ \\
\hline HFD + coffee with cloves & $7.54 \pm 0.58^{c}$ & $5.69 \pm 0.40^{a}$ & $12.29 \pm 0.73^{a}$ & $4.98 \pm 0.31^{a}$ \\
\hline
\end{tabular}

Values are means $\pm S D$ for six samples from 6 mice in each group; Values not sharing a common superscript differ significantly at $p \leq 0.05$. Duncan's Multiple Range Test (DMRT); U@= Enzyme concentration required for $50 \%$ inhibition of NBT reduction/minute

Table 3: Effect of Arabian coffee, cardamom and cloves on the activity of catalase in the erythrocyte and tissues of HFD-fed C57BL/6J mice

\begin{tabular}{lcccc}
\hline \hline \multirow{2}{*}{ Group } & Erythrocyte & \multicolumn{2}{c}{ CAT (U/mg protein) } \\
\cline { 3 - 5 } & $\begin{array}{c}\text { CAT } \\
\left(\mathbf{U}^{\star} / \mathbf{m g ~ H b}\right)\end{array}$ & Liver & Kidney & Heart \\
\hline \hline Control & $171.75 \pm 2.56^{\mathrm{a}}$ & $79.36 \pm 6.71^{\mathrm{a}}$ & $35.34 \pm 2.93^{\mathrm{a}}$ & $50.36 \pm 3.03^{\mathrm{a}}$ \\
Control + Arabian coffee & $173.21 \pm 7.60^{\mathrm{a}}$ & $80.81 \pm 7.84^{\mathrm{a}}$ & $36.94 \pm 3.12^{\mathrm{a}}$ & $51.99 \pm 3.52^{\mathrm{a}}$ \\
HFD & $104.81 \pm 6.62^{\mathrm{b}}$ & $45.78 \pm 2.64^{\mathrm{b}}$ & $17.83 \pm 1.33^{\mathrm{b}}$ & $26.63 \pm 2.02^{\mathrm{b}}$ \\
HFD + Arabian coffee + Cardamom & $150.63 \pm 3.74^{\mathrm{c}}$ & $60.30 \pm 1.35^{\mathrm{c}}$ & $25.32 \pm 2.12^{\mathrm{c}, \mathrm{d}}$ & $34.96 \pm 2.57^{\mathrm{c}}$ \\
HFD + Arabian coffee + Cardamom + cloves & $166.62 \pm 5.53^{\mathrm{e}}$ & $75.20 \pm 2.40^{\mathrm{e}}$ & $32.42 \pm 1.82^{\mathrm{c}}$ & $48.56 \pm 2.81^{\mathrm{e}}$ \\
HFD + coffee with cloves. & $153.24 \pm 4.28^{\mathrm{d}}$ & $65.32 \pm 1.59^{\mathrm{a}}$ & $28.51 \pm 2.45^{\mathrm{d}}$ & $42.32 \pm 3.25^{\mathrm{a}}$ \\
\hline \hline
\end{tabular}

Values are means $\pm S D$ for six samples from 6 mice in each group; Values not sharing a common superscript differ significantly at $p \leq 0.05$. Duncan's Multiple Range Test (DMRT); U* $-\mu \mathrm{mol}$ of $\mathrm{H}_{2} \mathrm{O}_{2}$ consumed/min

Effect of Arabian coffee, cardamom, and cloves on enzymatic and non-enzymatic antioxidants in erythrocytes and tissues of HFD-fed C57BL/6J mice

Table 2, Table 3, and Table 4 show the effect of Coffea Arabica L, cardamom and cloves on the activities of SOD, CAT, and GPX in the erythrocytes and tissues of HFD-fed mice. The activities of SOD, CAT, and GPx significantly decreased in HFD-fed mice and the consumption of Coffea Arabica $L$ plus cardamom resulted in a significant increase in these enzymes.

Table 5, Table 6 and Table 7 show the effect of Coffea Arabica L, cardamom, and cloves on the levels of vitamin $\mathrm{C}$, vitamin $\mathrm{E}$, and $\mathrm{GSH}$ in the erythrocytes and tissues of HFD-fed C57BL/6J mice. The levels of vitamin $\mathrm{C}$, vitamin $\mathrm{E}$, and GSH decreased significantly in HFD-fed mice and groups administered Coffea Arabica $L$, cardamom and cloves significantly exhibited increases in these parameters. 
Table 4: Effect of Arabian coffee, cardamom and cloves on the activity of glutathione peroxidase in the erythrocyte and tissues of HFD-fed C57BL/6Jmice

\begin{tabular}{lcccc}
\hline \hline \multirow{2}{*}{ Group } & Erythrocyte & \multicolumn{3}{c}{ GPx(U/mg protein) } \\
\cline { 3 - 5 } & $\begin{array}{c}\text { GPx } \\
\left(\mathbf{U}^{*} / \mathbf{m g ~ H b}\right)\end{array}$ & Liver & Kidney & Heart \\
\hline \hline Control & $16.21 \pm 1.19^{\mathrm{a}}$ & $9.25 \pm 0.88^{\mathrm{a}}$ & $10.85 \pm 0.75^{\mathrm{a}}$ & $8.25 \pm 0.35^{\mathrm{a}}$ \\
Control + Arabian coffee & $15.53 \pm 1.24^{\mathrm{a}}$ & $10.56 \pm 0.66^{\mathrm{a}}$ & $11.04 \pm 0.39^{\mathrm{a}}$ & $8.56 \pm 0.62^{\mathrm{a}}$ \\
HFD & $6.85 \pm 0.67^{\mathrm{b}}$ & $5.86 \pm 0.38^{\mathrm{b}}$ & $5.84 \pm 0.55^{\mathrm{b}}$ & $4.77 \pm 0.21^{\mathrm{b}}$ \\
HFD + Arabian coffee + Cardamom & $11.75 \pm 0.75^{\mathrm{c}, \mathrm{a}}$ & $6.21 \pm 0.34^{\mathrm{c}, \mathrm{a}}$ & $7.02 \pm 0.44^{\mathrm{c}}$ & $5.90 \pm 0.62^{\mathrm{c}}$ \\
HFD + Arabian coffee + Cardamom + cloves & $15.65 \pm 0.40^{\mathrm{e}}$ & $8.71 \pm 0.72^{\mathrm{c}}$ & $9.56 \pm 0.41^{\mathrm{e}, \mathrm{c}}$ & $7.30 \pm 0.56^{\mathrm{e}, \mathrm{c}}$ \\
HFD + coffee with cloves. & $13.61 \pm 1.67^{\mathrm{a}}$ & $7.26 \pm 0.45^{\mathrm{a}}$ & $8.53 \pm 0.69^{\mathrm{a}}$ & $6.43 \pm 0.41^{\mathrm{a}}$ \\
\hline \hline
\end{tabular}

Values are means $\pm S D$ for six samples from 6 mice in each group; values not sharing a common superscript differ significantly at $p \leq 0.05$. Duncan's Multiple Range Test (DMRT); $U^{*}-\mu g$ of GSH utilized/min

Table 5: Effect of Arabian coffee, cardamom and cloves on vitamin C in the plasma and tissues of HFD-fed C57BL/6J mice

\begin{tabular}{lcccc}
\hline \hline \multirow{2}{*}{ Group } & Plasma & \multicolumn{2}{c}{ Vitamin C $(\boldsymbol{\mu g} / \mathrm{mg}$ protein) } \\
\cline { 3 - 5 } & Vitamin C $(\mathrm{mg} / \mathrm{dL})$ & Liver & \multicolumn{1}{c}{ Kidney } & Heart \\
\hline \hline Control & $2.46 \pm 0.16^{\mathrm{a}}$ & $0.85 \pm 0.02^{\mathrm{a}}$ & $0.83 \pm 0.04^{\mathrm{a}}$ & $0.60 \pm 0.04^{\mathrm{a}}$ \\
Control + Arabian coffee & $2.92 \pm 0.28^{\mathrm{a}}$ & $0.89 \pm 0.07^{\mathrm{a}, \mathrm{e}}$ & $0.85 \pm 0.06^{\mathrm{a}}$ & $0.62 \pm 0.05^{\mathrm{a}}$ \\
HFD & $0.80 \pm 0.07^{\mathrm{b}}$ & $0.55 \pm 0.04^{\mathrm{b}}$ & $0.46 \pm 0.04^{\mathrm{b}}$ & $0.39 \pm 0.02^{\mathrm{b}}$ \\
HFD + Arabian coffee + Cardamom & $1.81 \pm 0.17^{\mathrm{c}}$ & $0.71 \pm 0.05^{\mathrm{c}}$ & $0.71 \pm 0.06^{\mathrm{c}, \mathrm{a}}$ & $0.41 \pm 0.04^{\mathrm{c}, \mathrm{a}}$ \\
HFD + Arabian coffee + Cardamom + & $2.18 \pm 0.19^{\mathrm{d}}$ & $0.79 \pm 0.03^{\mathrm{c}, \mathrm{e}}$ & $0.81 \pm 0.03^{\mathrm{a}, \mathrm{c}}$ & $0.55 \pm 0.03^{\mathrm{a}, \mathrm{c}}$ \\
cloves & $1.89 \pm 0.14^{\mathrm{c}}$ & $0.71 \pm 0.03^{\mathrm{d}}$ & $0.74 \pm 0.03^{\mathrm{a}}$ & $0.46 \pm 0.03^{\mathrm{d}}$ \\
HFD + coffee with cloves & & &
\end{tabular}

Values are means $\pm S D$ for six samples from 6 mice in each group. Values not sharing a common superscript differ significantly at $p \leq 0.05$. Duncan's Multiple Range Test (DMRT)

Table 6: Effect of Arabian coffee, cardamom and cloves on vitamin $E$ in the plasma and tissues of HFD-fed C57BL/6J mice

\begin{tabular}{llccc}
\hline \hline \multirow{2}{*}{ Group } & \multicolumn{2}{c}{ Plasma } & \multicolumn{3}{c}{ Vitamin E $(\mu \mathrm{g} / \mathrm{mg}$ protein) } \\
\cline { 3 - 5 } & \multicolumn{1}{c}{ Vitamin E $(\mathbf{m g} / \mathbf{d L})$} & Liver & \multicolumn{1}{c}{ Kidney } & Heart \\
\hline \hline Control & $1.90 \pm 0.06^{\mathrm{a}}$ & $6.40 \pm 0.41^{\mathrm{a}}$ & $4.61 \pm 0.35^{\mathrm{a}}$ & $5.48 \pm 0.37^{\mathrm{a}}$ \\
Control + Arabian coffee & $1.99 \pm 0.08^{\mathrm{a}}$ & $7.01 \pm 0.36^{\mathrm{a}}$ & $4.73 \pm 0.28^{\mathrm{a}}$ & $4.80 \pm .0 .27^{\mathrm{a}}$ \\
HFD & $0.89 \pm 0.04^{\mathrm{b}}$ & $3.72 \pm 0.17^{\mathrm{b}}$ & $1.52 \pm 0.16^{\mathrm{b}}$ & $2.77 \pm 0.14^{\mathrm{b}}$ \\
HFD + Arabian coffee + Cardamom & $1.57 \pm 0.04^{\mathrm{c}}$ & $5.66 \pm 0.29^{\mathrm{c}}$ & $3.62 \pm 0.13^{\mathrm{C}}$ & $3.99 \pm 0.28^{\mathrm{C}}$ \\
HFD + Arabian coffee + Cardamom + cloves & $1.73 \pm 0.11^{\mathrm{e}}$ & $5.99 \pm 0.46^{\mathrm{a}, \mathrm{e}}$ & $4.23 \pm 0.30^{\mathrm{a}, \mathrm{e}}$ & $5.19 \pm 0.36^{\mathrm{a}, \mathrm{e}}$ \\
HFD + coffee with cloves & $1.60 \pm 0.10^{\mathrm{a}}$ & $5.75 \pm 0.34^{\mathrm{a}}$ & $4.03 \pm 0.29^{\mathrm{d}}$ & $4.40 \pm 0.38^{\mathrm{a}}$ \\
\hline \hline
\end{tabular}

Values are means $\pm S D$ for six samples from 6 mice in each group; Values not sharing a common superscript differ significantly at $p \leq 0.05$. Duncan's Multiple Range Test (DMRT)

Table 7: Effect of Arabian coffee, cardamom and cloves on reduced glutathione in the plasma and tissues of HFD-fedC57BL/6J mice

\begin{tabular}{lcccc}
\hline \hline \multirow{2}{*}{ Group } & Plasma GSH & \multicolumn{3}{c}{ GSH $(\boldsymbol{\mu g} / \mathbf{m g}$ protein) } \\
\cline { 3 - 5 } & $(\mathbf{m g} / \mathbf{d L})$ & Liver & Kidney & Heart \\
\hline \hline Control & $31.22 \pm 2.41 \mathrm{a}$ & $10.98 \pm 0.79 \mathrm{a}$ & $11.12 \pm 0.72 \mathrm{a}$ & $9.22 \pm 0.42 \mathrm{a}$ \\
Control + Arabian coffee & $30.83 \pm 2.52 \mathrm{a}$ & $11.56 \pm 0.72 \mathrm{a}$ & $10.56 \pm 0.75 \mathrm{a}$ & $9.37 \pm 0.61 \mathrm{a}$ \\
HFD & $17.73 \pm 1.11 \mathrm{~b}$ & $8.52 \pm 0.61 \mathrm{~b}$ & $5.56 \pm 0.15 \mathrm{~b}$ & $5.50 \pm 0.40 \mathrm{~b}$ \\
HFD + Arabian coffee + Cardamom & $26.73 \pm 1.51 \mathrm{c}$ & $9.71 \pm 0.35 \mathrm{c}$ & $7.95 \pm 0.61 \mathrm{c}$ & $6.78 \pm 0.62 \mathrm{c}$ \\
HFD + Arabian coffee + Cardamom + cloves & $29.91 \pm 1.74 \mathrm{a}, \mathrm{d}$ & $10.11 \pm 0.54 \mathrm{~d}, \mathrm{c} 9.67 \pm 0.49 \mathrm{~d}$ & $8.57 \pm 0.62 \mathrm{~d}, \mathrm{a}$ \\
HFD + coffee with cloves & $27.29 \pm 1.16 \mathrm{c}, \mathrm{d}$ & $9.76 \pm 0.77 \mathrm{~d}$ & $8.78 \pm 0.55 \mathrm{~d}$ & $7.92 \pm 0.64 \mathrm{~d}, \mathrm{a}$ \\
\hline \hline
\end{tabular}

Values are means $\pm S D$ for six samples from 6 mice in each group; Values not sharing a common superscript differ significantly at $p \leq 0.05$. Duncan's Multiple Range Test (DMRT) 
Table 8: Effect of Arabian coffee, cardamom and cloves on the levels of oxLDL-Ab and PON aryl esterase activities in the plasma of HFD-fed C57BL/6Jdiabetic mice

\begin{tabular}{lcc}
\hline \hline Groups & $\begin{array}{c}\text { PON1 aryl esterase activity } \\
\text { (U/mg protein) }\end{array}$ & $\begin{array}{c}\text { oxLDL-Ab } \\
\text { (EU/mL) }\end{array}$ \\
\hline \hline Control & $58.87 \pm 4.41 \mathrm{a}$ & $18.17 \pm 2.41 \mathrm{a}$ \\
Control + Arabian coffee & $32.12 \pm 2.12 \mathrm{c}$ & $30.12 \pm 2.12 \mathrm{a}$ \\
HFD & $18.73 \pm 1.41 \mathrm{e}$ & $39.13 \pm 1.87 \mathrm{~d}$ \\
HFD + Arabian coffee + Cardamom & $39.78 \pm 1.88 \mathrm{~b}$ & $26.78 \pm 1.88 \mathrm{~b}$ \\
HFD + Arabian coffee + Cardamom + cloves & $28.91 \pm 1.24 \mathrm{~d}$ & $29.91 \pm 1.09 \mathrm{c}$ \\
HFD + coffee with cloves & $27.01 \pm 1.06 \mathrm{~d}$ & $28.11 \pm 1.11 \mathrm{c}$ \\
\hline \hline
\end{tabular}

Values are means $\pm S D$ for six samples from 6 mice in each group; Values not sharing a common superscript differ significantly at $p \leq 0.05$. Duncan's Multiple Range Test (DMRT)

Effect of Arabian coffee, cardamom, and cloves on the levels of plasma oxLDL $A b$ and PON1 arylesterase activity in the plasma of HFD-fed mice

Table 8 shows the effect of Coffea Arabica $L$, cardamom and cloves on the levels of plasma oxLDL $A b$ and PON1 activity in the plasma of HFD-fed mice. The levels of oxLDL Ab increased, whereas PON1 activity decreased significantly in HFD-fed mice. In the groups consuming Coffea Arabica L, cardamom and cloves, these parameters were similar to those of the non-HFD-fed control group. The effect was pronounced in groups fed Coffea Arabica $L$ plus cardamom.

\section{DISCUSSION}

Administration of a HFD is a well-established method for altering the antioxidant defense mechanism against lipid peroxidation. Lipid peroxidation and non-enzymatic glycosylated proteins are sources of free radicals, including superoxide and hydrogen peroxide [22], which are responsible for a weakened antioxidant defense system in those with hyperlipidemia. Free-radical-scavenging enzymes (SOD, CAT, and GPx) are part of a preliminary defense mechanism, which is involved in eliminating superoxide anions and hydrogen peroxide. In the present study, administration of a HFD supplemented with Arabian coffee resulted in a significant elevation in enzymatic antioxidants. This result indicated that the compounds present in the decoction protected the tissues from lipid peroxidation owing to their antioxidant ability and, consequently, allowed for a reduction in lipid peroxidation. Studies have shown that oxLDL plays an important role in the progression of atherosclerosis, which results from abnormal lipid levels [23,24]. Elevated levels of oxLDL Ab indicate an accelerated atherosclerotic process. PON1 prevents LDL oxidation, which is an initial step in the development of atherosclerosis $[25,26]$. This evidence indicates that decreased PON1 activity is associated with increased lipid peroxidation in diabetes and that it might be a factor determining the predisposition to complications of diabetes. LDL particles are protected from oxidation in plasma by the antioxidant enzyme PON1, whereas LDL particles trapped within artery walls are prone to oxidative damage [27]. Tocopherol is the most active form of vitamin $E$ and the most abundant lipid-soluble antioxidant in LDL [28]. $\alpha-$ Tocopherol may also act as a phase-transfer agent. However, it was reported that ascorbate inhibited the tocopheroxyl radical ( $\alpha-T o c-O \bullet)[27]$.

Low levels of vitamin C, vitamin E, PON1, and GSH in HFD-fed mice, along with increased oxLDL $A b$ levels, represented the hallmark of atherosclerosis. Low levels of vitamin E in HFDfed mice could be due to an increased utilization of vitamin $E$ for scavenging radicals or to decreased levels of vitamin $C$ because there is a well-established synergism between vitamins $C$ and $E$ [29]. Depletion of GSH in HFD-fed mice is likely due to consumption of GSH by electrophilic compounds like lipoperoxidation aldehydes. Treatment with Arabian coffee increased antioxidants and reduced lipid peroxidation and oxLDL Ab levels. Moreover, a reduction in plasma oxLDL Ab levels and elevation of PON1 activity in Arabian coffee-treated mice indicated that Arabian coffee improved the antioxidant properties of HDL.

\section{CONCLUSION}

The antioxidant properties of Arabian coffee, as indicated in this study, support its traditional medicinal use in Saudi and several other parts of the world. In addition, as inferred from the results, Arabian coffee plus cardamom exhibited potential antioxidant properties and counteracted free radicals generated by the HFD.

\section{DECLARATIONS}

\section{Acknowledgement}

We gratefully acknowledge the financial support 
from the Research Center, Deanship of Scientific Research, College of Food and Agricultural Sciences, King Saud University, Riyadh, Kingdom of Saudi Arabia.

\section{Conflict of Interest}

No conflict of interest associated with this work.

\section{Contribution of Authors}

The authors declare that this work was done by the authors named in this article and all liabilities pertaining to claims relating to the content of this article will be borne by them.

\section{Open Access}

This is an Open Access article that uses a funding model which does not charge readers or their institutions for access and distributed under the terms of the Creative Commons Attribution License (http://creativecommons.org/licenses/by/ 4.0) and the Budapest Open Access Initiative (http://www.budapestopenaccessinitiative.org/rea d), which permit unrestricted use, distribution, and reproduction in any medium, provided the original work is properly credited.

\section{REFERENCES}

1. Memish ZA, El Bcheraoui C, Tuffaha M, Robinson $M$, Daoud F, Jaber S, Mikhitarian S, Al Saeedi M, AIMazroa MA, Mokdad AH, Al Rabeeah AA. Obesity and associated factors -Kingdom of Saudi Arabia, 2013. Prev Chronic Dis 2014; 11: e174.

2. Esterbauer H, Gebicki J, Puhl H, Jurgens G. The role of lipid peroxidation and antioxidants in oxidative modifications of LDL [Rev]. Free Radic Biol Med 1992; 13: 341-390.

3. Esterbauer H, Schaur JS, Zollner H. Chemistry and biochemistry of 4-hydroxynonenal, malondialdehyde and related aldehydes. Free Radic Biol Med 1991; 11: 81 128.

4. Knecht $K T$, Bradford BU, Mason RP, Thurman RG. In vivo formation of a free radical metabolite of ethanol. Mol Pharmacol 1990; 38: 26-30.

5. Ferretti G, Bacchetti T, Busni D, Rabini RA, Curatola G. Protective effect of paraoxonase activity in high-density lipoproteins against erythrocyte membranes peroxidation a comparison between healthy subjects and type 1 diabetic patients. J Clin Endocrinol Metab 2004; 89: 2957-2962.

6. Van Lenten BJ, Hama $S Y$, de Beer FC, Stafforini DM, Mclntyre TM, Prescott SM, La Du BN, Fogelman AM, Navab M. Anti-inflammatory HDL becomes proinflammatory during the acute phase response. Loss of protective effect of $H D L$ against $L D L$ oxidation in aortic wall cell co-cultures. J Clin Invest 1995; 96: 2758-2767.

7. Schaefer B. Coffee consumption and type 2 diabetes mellitus. Ann Intern Med 2004; 141: 323-324.

8. Butt MS, Sultan MT. Coffee and its consumption benefits and risks. Crit Rev Food Sci Nutr 2011; 51: 363-373.

9. Klatsky AL, Morton C, Udaltsova N, Friedman GD. Coffee, cirrhosis and transaminase enzymes. Arch Intern Med 2006; 166: 1190-1195.

10. Wilson KM Kasperzyk JL, Rider JR, Kenfield S, van Dam RM, Stampfer MJ, Giovannucci E, Mucci LA. Coffee consumption and prostate cancer risk and progression in the health professional follow up study. J Natl Cancer Inst 2011; 103: 876-884.

11. Huxley R, Lee CM, Barzi F, Timmermeister L, Czernichow S, Perkovic V, Grobbee DE, Batty $D$, Woodward M. Coffee decaffeinated coffee and tea consumption in relation to incident type 2 diabetes: a systematic review with meta-analysis. Arch Intern Med 2009; 169: 2053-2063.

12. Olfat NM, Norah M, Qahiz Al, Mohamed SI. Different doses of Arabic coffee improve serum lipid profile, uric acid and liver enzymes of experimental rats. Food Public Health 2013; 3: 228-233.

13. Guide to the Care and Use of Experimental Animals: Canadian Council on Animal Care. Volume 1 (2nd. Edition), 1993. (Adopted May 1999) Canadian Council on Animal Care, 315-350 Albert St., Ottawa, Ontario, Canada, K1R $1 B 1$.

14. Ohkawa H, Ohishi N, Yagi K. Assay of lipid peroxidation in animal tissues by thiobarbituric acid reaction. Anal Biochem 1979; 95: 35-58.

15. Kakkar PS, Das BB, Viswanathan PN. A modified spectrophotometric assay of superoxide dismutase. Indian J Biochem Biophys 1984; 21(2): 130-132.

16. Sinha KA. Colorimetric assay of catalase. Anal Biochem 1972; 47: 89-94.

17. Ellman GL. Tissue sulfhydryl groups. Arch Biochem Biophys 1959; 82(1): 70-77.

18. Rotruck JT, Pope AL, Ganther HE, Swanson AB, Haseman DG, Hoekstra WG. Selenium: biochemical role as a component of glutathione peroxidase. Science 1973;90: 179: 588.

19. Roe HJ, Kuether CA. Detection of ascorbic acid in whole blood and urine through the 2, 4-dinitrophenyl-hydrazine derivative of dehydroascorbic acid. J Biol Chem 1943; 147: 399-407.

20. Baker H, Frank O, De Angelis B, Feingod S. Plasma tocopherol in man at various times after ingesting free or acetylated tocopherol. Nutr Rep Int 1980; 21: 531-536.

21. Cabana VG, Reardon CA, Feng N, Neath S, Lukens J, Getz GS. Serum paraoxonase effect of the apolipoprotein composition of HDL and the acute phase response. J Lipid Res 2003; 44: 780-92.

22. Goode HF, Gilbey SG, Wobster NR, Walker BE. The proceedings of the nutrition society 1994; 53: 195 A. 
23. Holvoet $P$, Collen $D$, Van de Werf F. Malondialdehyde modified $L D L$ as a marker of acute coronary syndromes. JAMA 1999; 21: 281-1718.

24. Holvoet $P$, Vanhaecke J, Janssens $S$, Van de Werf $F$, Collen D. Oxidized $L D L$ and malondialdehyde-modified $L D L$ in patients with acute coronary syndromes and stable coronary artery disease. Circulation 1998; 98 : 1487-1494.

25. Mackness MI, Arrol S, Durrington PN. Paraoxonase prevents accumulation of lipoperoxides in low-density lipoprotein. FEBS LETT 1991; 286: 152-154.

26. Mackness MI, Arrol S, Abbott CA, Durrington PN. Protection of low-density lipoprotein againstoxidative modification by high-density lipoprotein associated paraoxonase. Atherosclerosis 1993; 104: 129-135.

27. Osterud B, Bjorklid E. Role of monocytes in atherogenesis. Physiol Rev 2003; 83: 1069-1112.

28. Bowry VW, Ingold KU, Stocker R. Vitamin $E$ in human low-density lipoprotein. When and how this antioxidant becomes a pro-oxidant. Biochem J 1992; 288: 341-344.

29. Kaviarasan K, Kalaiarasi P, Pugalendi KV. Antioxidant efficacy of flavonoid-rich fraction from Spermacoce hispida in hyperlipidemic rats. J Appl Biomed 2008; 6: 165-176. 